KREATIF

Jurnal Ilmiah

Prodi Manaiemen Universitas Pamulang
Pamulang ISSN : $2339-0689$, E-ISSN : 2406-8616

J. KREATIF, Vol. 7, No. 2, Desember 2019 (Halaman 92-103)

Tersedia Online di : http://openjournal.unpam.ac.id/index.php/kreatif

\title{
PENGARUH CURRENT RATIO (RASIO LANCAR) DAN DEBT TO \\ TOTAL ASSETS RATIO (RASIO UTANG) TERHADAP PERUBAHAN \\ LABA (KEUNTUNGAN) PADA PT ASTRA AGRO LESTARI TBK. PERIODE 2012-2016
}

\author{
Ugeng Budi Haryoko', Amalia Syahida ${ }^{2}$ \\ Program Studi Manajemen \\ ${ }^{1}$ Dosen Universitas Pamulang \\ ${ }^{2}$ Alumni Universitas Pamulang \\ ugengbudiunpam@gmail.com
}

\begin{abstract}
ABSTRAK
Hasil Uji signifikan parsial (Uji t) terhadap variabel Current Ratio diperoleh hasil thitung $(1,529)<$ ttabel $(2,919)$, artinya tidak ada pengaruh rasio lancar terhadap perubahan laba. Hasil Uji signifikan parsial (Uji t) terhadap variabel Debt To Total Assets Ratio diperoleh hasil thitung $(-1,275)<$ ttabel $(-2,919)$, artinya tidak ada pengaruh rasio hutang terhadap perubahan laba. Hasil Uji signifikan simultan (Uji F) diperoleh hasil hasil Fhitung $(2,104)<$ Ftabel $(19,00)$, artinya tidak ada pengaruh rasio lancar dan rasio hutang secara bersama-sama terhadap perubahan laba.

Kata Kunci : Rasio Lancar (Current Ratio), Rasio Utang (Debt To Total Assets Ratio) dan Perubahan Laba

\section{ABSTRACT}

The results of the partial significant test ( $t$ test) on the Current Ratio variable obtained results of tcount $(1,529)<$ ttable $(2,919)$ means that there is no effect of the current ratio on changes in earnings. The results of the partial significant test ( $t$ test) on the Debt To Total Assets Ratio variable obtained the results of tcount $(-1,275)<t$ table $(-2,919)$, meaning there is no effect on the debt ratio to changes in earnings. Simultaneous significant test results (Test $F$ ) obtained results of Fcount (2.104) <Ftable (19.00), meaning there is no effect of current ratio and debt ratio together on changes in earnings.
\end{abstract}

Keywords: Current Ratio, Debt To Total Assets Ratio and Profit Changes

\section{PENDAHULUAN}

A. Latar Belakang

Perkembangan dunia bisnis yang semakin kompetitif di Indonesia mengharuskan setiap perusahaan dapat memproses dan menerapkan manajemen perusahaan untuk menjadi lebih profesional. Hal ini disebabkan oleh munculnya sejumlah besar pesaing di dunia bisnis, baik pesaing domestik maupun asing, sehingga setiap perusahaan berusaha untuk terus meningkatkan kinerja perusahaan yang baik untuk keberadaan dan kontinuitas perusahaan. 
Selain laba, "kinerja perusahaan" biasa diukur dengan menggunakan rasiorasio keuangan. Rasio menggambarkan suatu hubungan antara suatu jumlah tertentu dengan jumlah yang lain. Dengan menggunakan analisis berupa laporan keuangan maka akan dijelaskan dan diberikan gambaran tentang baik atau buruknya posisi keuangan perusahaan. Jenis rasio keuangan yang bisa digunakan dalam memprediksi laba ada banyak jenisnya.Para peneliti umumnya menetapkan jenis rasio sesuai dengan kebutuhannya. Sebahagian rasio yang dipakai adalah rasio lancar, rasio utang, rasio keaktifan, rasio laba.

Dalam penulisan penelitian ini penulis menganalisa tentang Current Ratio (CR), Debt To Total Assets Ratio (DAR) dan perubahan laba yang tercetak dalam tabulasi 1.1 sebagai berikut :

\section{Tabulasi}

Current Ratio (CR), Debt To Total Assets Ratio (DAR) dan Perubahan Laba PT Astra Agro Lestari TbkPeriode Tahun 2012-2016

\begin{tabular}{|c|c|c|c|}
\hline Tahun & CR & DAR & Perubahan Laba \\
\hline 2012 & $0,68 X$ & $24 \%$ & 0,0087 \\
\hline 2013 & $0,45 X$ & $31 \%$ & $-0,2449$ \\
\hline 2014 & $0,58 X$ & $36 \%$ & 0,3778 \\
\hline 2015 & $0,79 X$ & $46 \%$ & $-0,7346$ \\
\hline 2016 & $1,03 X$ & $27 \%$ & 2,0392 \\
\hline
\end{tabular}

Sumber : PT Astra Agro Lestari Periode 2012-2016

Dalam tabel diatas menunjukan Current Ratio yang dicapai oleh PT Astra Agro Lestari pada tahun 2012-2016 mengalami fluktuatif. Sedangkan Debt To Total Assets Ratio selama lima tahun terakhir, terhitung dari tahun 20122016 menunjukan kondisi tidak stabil. Berdasarkan dari tabel diatas juga menunjukan perubahan laba yang fluktuatif pada tahun 2012-2016.

\section{B. Rumusan Masalah}

Berlandaskan kerangka masalah, perumusan masalah dalam telaah ini ialah :

1. Apa impak rasio lancar kepada perubahan keuntungan di perusahaan PT Astra Agro Lestari Tbk Periode 2012-2016?

2. Apa impak rasio utang kepada perubahan keuntungan di perusahaan PT Astra Agro Lestari Tbk Periode 2012-2016?

2. Seberapa besar pengaruh rasio lancar dan rasio utang secara simultan kepada perubahan keuntungan di perusahaan PT Astra Agro Lestari Tbk Periode 2012-2016?

\section{TANJAUAN PUSTAKA}

\section{A. Manajemen Keuangan}

Berdasarkan Darsono (2011:2) Manajemen keuangan adalah “ merupakan aktivitas pemilik dan meminjam perusahaan untuk memperoleh sumber modal yang semurah-murahnya dan menggunakan seefektif, seefisien, dan seekonomis mungkin untuk menghasilkan laba".

\section{B. Rasio Keuangan}


Untuk pada Agus Sartono (2010:113) yang dimaksud dengan rasio keuangan adalah " untuk menilai dan mengarahkan prestasi operasi perusahaan. Disamping itu, rasio keuangan dapat dipergunakan sebagai kerangka kerja perencanaan dan pengendalian keuangan”.

\section{Rasio Lancar}

Pada Sutrisno (2013:247) Rasio lancar adalah " rasio yang paling sering membandingkan antara aset lancar yang dimiliki perusahaan dan utang jangka pendek. Aset lancar termasuk uang tunai, piutang, sekuritas, inventaris, dan aset lancar lainnya. Sedangkan utang jangka pendek meliputi utang dagang, wesel bayar, pinjaman bank, utang gaji, dan utang lain yang harus dibayar".

Rasio ini dapat dihitung dengan rumus sebagai berikut :

\section{Rasio Utang}

$$
\text { Current Ratio }=\frac{\text { Aset Lancar }}{\text { Utang Lancar" }} \mathrm{X}
$$

Rasio yang biasa disebut dengan rasio utang (debt ratio) ini mengukur prosentase besarnya dana yang berasal dari hutang. Hutang yang dimaksud adalah semua hutang yang dimiliki oleh perusahaan baik yang berjangka pendek maupun yang berjangka panjang.Kreditor lebih menyukai debt ratio yang rendah sebab" tingkat keamanan dananya menjadi semakin baik, Sutrisno (2013:249)". Untuk mengukur besarnya rasio ini digunakan rumus:

$$
\text { Total Debt to Total Assets Ratio }=\frac{\text { "Total Hutang }}{\text { Total Aktiva }}
$$

Rasio ini menunjukkan sejauh mana utang dapat ditutupi oleh aset. Semakin kecil rasio semakin aman (dipecahkan). Utang utang ke aset harus lebih kecil.

E. Pengertian Perubahan Laba

Menurut Dhany dan Andhi (2015:46) perubahan keuntungan adalah "peningkatan laba atau penurunan pendapatan per tahun. Penilaian tingkat keuntungan pengembalian investasi oleh investor didasarkan oleh kinerja keuangan perusahaan, dapat dilihat dari tingkat perubahan laba dari tahun ke tahun".

Sedangkan menurut Harahap (2013:310) perubahan keuntungan adalah “ diperoleh berdasarkan perbedaan antara laba pada periode tertentu dan periode sebelumnya dibagi dengan laba pada periode sebelumnya".

Rumus perhitungan perubahan keuntungan :

Perubahan Keuntungan

$$
=\frac{\text { Laba Bersih Tahun Ini }- \text { Laba Bersih Tahun Lalu }}{\text { Laba Bersih Tahun Lalu }}
$$

\section{F. Konteks Pemikiran}

Pada konteks pemikiran ini, penyusun menguraikan dalam bentuk bagan sebagai berikut : 


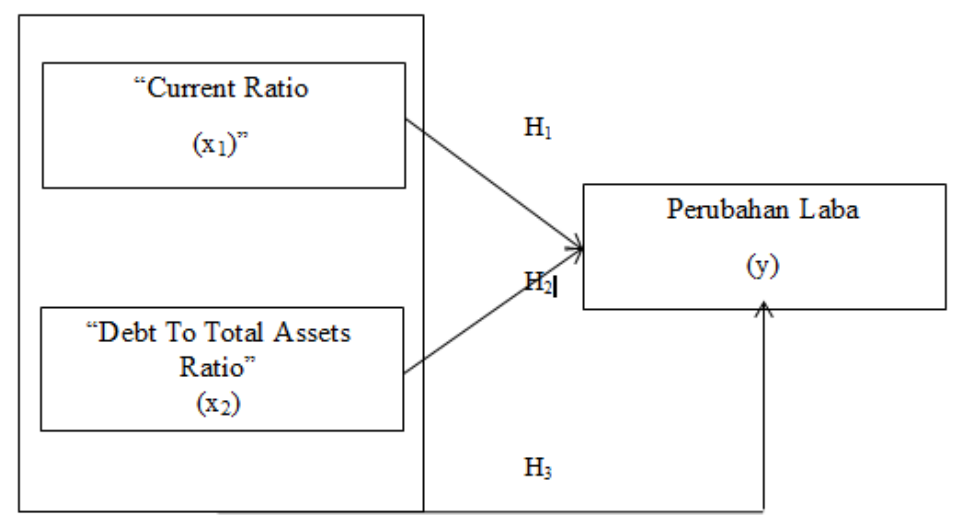

Gambar Kerangka Pemikirian

\section{G. Hipotesis}

Proposisi adalah "merupakan pernyataan atau dugaan yang bersifat sementara terhadap suatu masalah penelitian yang kebenarannya masih lemah (belum tentu kebenarannya) sehingga harus diuji secara empiris". Berdasarkan teori dan hasil telaah yang membahas rasio likuiditas dan solvabilitas terhadap perubahan laba dengan menggunakan rasio keuangan, maka proposisi dalam telaah ini yakni :

$\mathrm{Ha}_{1}$ :Adanya pengaruh Current Ratioperusahaan terhadap Perubahan Laba PTAstra Agro Lestari Tbk.

$\mathrm{Ha}_{2}$ : Adanya pengaruh Debt to AssetsRatioperusahaan terhadap Perubahan LabaPT Astra Agro Lestari Tbk.

$\mathrm{Ha}_{3}$ :Adanya pengaruh rasio lancar dan rasio utang secara Simultan terhadap Perubahan keuntungan PTAstra Agro Lestari Tbk.

\section{METODE PENELITIAN}

\section{A. Uji Asumsi Klasik}

Berdasarkan tujuan penelitian yaitu untuk memahami pengaruh rasio lancar dan rasio utang secara simultan kepada perubahan keuntungan perusahaan PT Astra Agro Lestari Tbk Periode 2012-2016. Maka menggunakan sifat penelitian deskriftif kuantitatif deskriptif , maksudnya telaah yang menggambarkan atau memberi tahu dan menjelaskan bagaimana hasil perhitungan data keuangan perusahaan dalam bentuk laporan keuangan. Adapun teknik "digunakan dalam sampling yaitu : Probability sampling dan non probabilty sampling, dengan teknikanalisis data yaitu" :

"Sebuah uji asumsi klasik terdiri dari: uji normalitas, uji multikolinearitas, uji heterokedastisitas, dan uji autokorelasi".

\section{B. Koefisien Korelasi}

Untuk pada Ghozali (2010:9) Analisis Korelasi adalah “ untuk mengukur kekuatan asosiasi (hubungan) linear antara dua variabel. Besarnya koefisien mengukur kuatnya asosiasi linear".

\section{Koefisien Determinasi}

Pada Priyatno (2012:134) R Square (R2) adalah "menunjukan koefisien determinan. Angka ini akan diubah menjadi persen, yang berarti persentase kontribusi variabel independen terhadap variabel dependen". 
"Jika nilai koefisien determinasi sama dengan $0(\mathrm{R} 2=0)$, itu berarti bahwa variasi $\mathrm{Y}$ tidak dapat dijelaskan dengan $\mathrm{X}$ sama sekali. Sedangkan jika R2 = 1 , artinya variasi dari $\mathrm{Y}$ secara simultan dapat diterangkan oleh $\mathrm{X}$. Dengan kata lain, bila $\mathrm{R} 2=1$, maka semua titik pengamatan berada tepat pada garis regresi. Dengan demikian baik atau buruknya suatu persamaan regresi ditentukan oleh R2 nya yang mempunyai nilai antara 0 dan 1 ".

\section{Koefisien Regresi Linier Berganda}

Temalagi dan Latan (2013:84) Analisis regresi linier berganda adalah "merupakan teknik analisis regresi yang dapat digunakan untuk mengkaji pengaruh beberapa variabel independen terhadap satu variabel dependen.Dalam regresi linier berganda ditetapkan bila terdapat variabel independen minimal dua atau lebih dari dua. Persamaan linier berganda untuk ketiga "variabel ini adalah :

$\mathbf{Y}=\mathbf{a}+\mathbf{b}_{1} \mathbf{X}_{1}+\mathbf{b}_{2} \mathbf{X}_{2}$

Keterangan :

Y : Perubahan Laba

a : Konstanta

b1, b2, b3 :Koefisien regresi, menunjukan angka naik turunnya variabel independen.

$\mathrm{X} 1, \mathrm{X} 2 \quad$ : Variabel yang mempunyai nilai tertentu, dalam penelitian ini yaitu $\mathrm{X}_{1}$ (Rasio Lancar) dan $\mathrm{X}_{2}$ (Rasio Utang)

Berdasarkan perumusan ,kemudian persesuaianyang diajukan ialah:

Perubahan Laba: $\mathbf{Y}=\mathbf{a}+\mathbf{b}_{1} \mathbf{X}_{1}+\mathbf{b}_{2} \mathbf{X}_{2}$

E. Uji Hipotesis

Uji t parsial

Pada Priyatno (2012:139) uji t atau uji koefisien regresi secara parsial adalah "digunakan untuk mengetahui apakah secara parsial variabel independen berpengaruh secara signifikan atau tidak terhadap variabel dependen"."Dalam hal ini untuk mengetahui apakah secara parsial variabel" Current Ratio dan Debt to Assets Ratio terhadap perubahan laba. Hasil uji T dapat dilihat pada output coefficients dari hasil analisis regresi berganda. Nilai dari uji $\mathrm{T}$ dapat dilihat dengan menggunakan tingkat hubungan $0.05 \mathrm{a}=$ $5 \%$ ). Berdasarkan signifikan $<0,05$ maka Ho ditampik, dan jika signifikansi $>0,05$ maka Ho disahkan.

Hipotesis / Proposisi :

"Ho : Tidak ada pengaruh variabel $\mathrm{X}_{1}, \mathrm{X}_{2}$ secara parsial pada variabel $\mathrm{Y}$ "

"Ha : Ada pengaruh variabel $\mathrm{X}_{1}, \mathrm{X}_{2}$ secara parsial pada variabel $\mathrm{Y}$ "

Uji F Simultan

Menurut Priyatno (2012:137) uji F atau uji koefisien regresi secara bersamasama adalah "digunakan untuk mengetahui apakah secara bersama-sama variabel independen berpengaruh signifikan terhadap variabel dependen. Nilai dari uji $\mathrm{F}$ dapat dilihat dengan menggunakan tingkat signifikansi 0.05 (a $=5 \%$ ). Berdasarkan signifikansi, jika signifikansi <0,05 maka Ho diterima, sedangkan signifikansi $0,05>$ maka Ho diterima".

Hipotesis :

"Ho : Tidak ada pengaruh variabel $\mathrm{X}_{1}$ dan $\mathrm{X}_{2}$ secara simultan pada variabel $Y$ "

"Ha : Ada pengaruh variabel $\mathrm{X}_{1}$ dan $\mathrm{X}_{2}$ secara simultan pada variable $\mathrm{Y}$ “ 


\section{HASIL PENELITIAN}

\section{A. Hasil Uji Asumsi Klasik}

\section{Uji Normalitas}

Distribusi normal akan membentuk suatu garis diagonal dan ploting data akan dibandingkan dengan garis diagonal dan dengan pengujian histogram, hasil sebagai berikut :

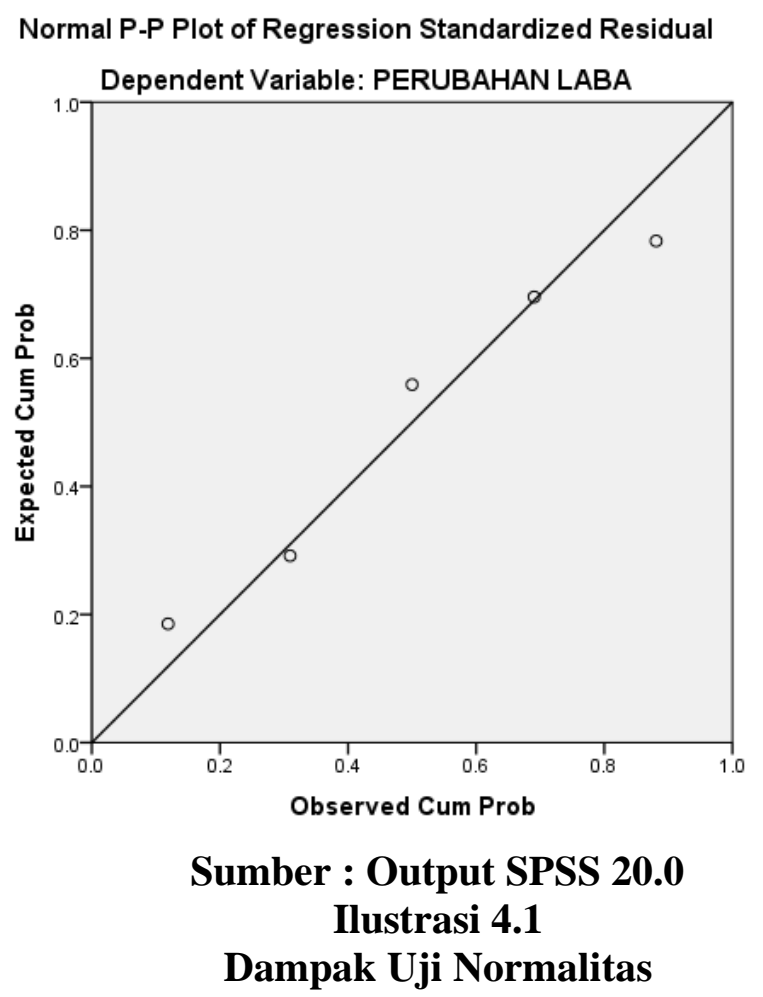

Pada ilustrasi 4.1 terlihat bahwa tebaran bukti tersebar di sekitar garis diagonal atau tidak tersebar jauh dari garis lurus.Ini berarti bahwa model regresi normal atau mendekati normal sehingga layak dalam penelitian.

\section{Multikolinieritas}

Tabulasi

Uji Multikolinieritas

Coefficients $^{\mathrm{a}}$

\begin{tabular}{|c|c|c|c|c|c|c|c|}
\hline \multirow{2}{*}{ Model } & \multicolumn{2}{|c|}{$\begin{array}{l}\text { Unstandardized } \\
\text { Coefficients }\end{array}$} & \multirow{2}{*}{$\begin{array}{c}\begin{array}{c}\text { Standardize } \\
\mathrm{d} \\
\text { Coefficients }\end{array} \\
\text { Beta }\end{array}$} & \multirow{2}{*}{$\mathrm{T}$} & \multirow{2}{*}{ Sig. } & \multicolumn{2}{|c|}{ Collinearity Statistics } \\
\hline & B & $\begin{array}{l}\text { Std. } \\
\text { Error }\end{array}$ & & & & Tolerance & VIF \\
\hline $\begin{array}{l}\text { (Constan } \\
\text { t) }\end{array}$ & .350 & 2.278 & & .153 & .892 & & \\
\hline $1 \mathrm{CR}$ & 2.966 & 1.939 & .615 & 1.529 & .266 & .997 & 1.003 \\
\hline DAR & -6.549 & 5.138 & -.513 & 1.275 & .330 & .997 & 1.003 \\
\hline
\end{tabular}

a. Variabel Terikat : PERUBAHAN LABA

Dari: Output SPSS 20.0 
Berdasarkan tabel 4.1 dapat diliat nilai variance inflation (VIF) "masingmasing variable"independen "memiliki VIF tidak lebih 10 dan nilai tolerance tidak kurang dari 0,1 ". "Dengan demikian, dapat disimpulkan bahwa semua variabel independen tidak terjadi permasalahan multikolinieritas dan dapat digunakan sebagai data penelitian".

\section{Heteroskedastisitas}

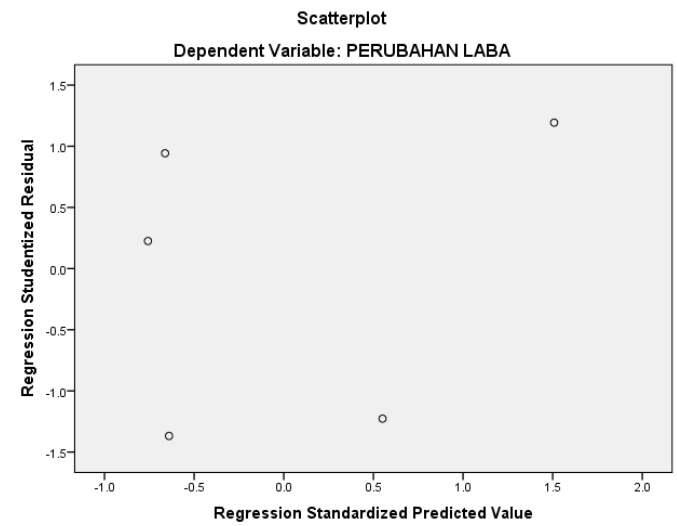

Dari: Keluaran SPSS 20.0

\section{Ilustrasi}

\section{Uji Heteroskedastisitas}

Dari ilustrasi 4.2 Scattertplot tersebut terlihat bahwa titik-titik menyebar secara acak, tidak membentuk pola tertentu, serta tersebar di atas atau di bawah angka 0 pada sumbu $\mathrm{Y}$.

Hal ini dapat dikatakan bahwa itu tidak terjadi" heteroskedastisitas "pada model regresi ini, sebatas pantas dipergunakan sebagai data penelitian.

\section{Autokorelasi}

Tabulasi

Uji Autokorelasi

Runs Test

\begin{tabular}{|l|r|}
\hline & $\begin{array}{r}\text { Unstandardi } \\
\text { zed Residual }\end{array}$ \\
\hline Test Value $^{\mathrm{a}}$ & .12606 \\
Cases < Test & 2 \\
Value & \\
Cases >= Test & 3 \\
Value & 5 \\
Total Cases & 4 \\
Number of Runs & .109 \\
$Z$ & .913 \\
Asymp. Sig. (2- & 5 \\
tailed) &
\end{tabular}

a. Median

"Dari : Keluaran SPSS 20.0"

Pada hasil tes statistik run test" di atas diperoleh nilai signifikan asimptotik sebanyak 0,913 (lewat dari 0,05). Karena nilai asymptotic significant value di atas 0,05 maka dapat ditarik kesimpulan bahwa untuk hipotesis nol ( $\mathrm{H} 0)$ bersifat residual random (acak) dan data tidak terjadi gangguan autokorelasi. 


\section{B. Koefisien Korelasi}

\section{Tabulasi}

Koefisien Korelasi

Model Summary

\begin{tabular}{|c|c|c|c|c|c|c|c|c|c|c|}
\hline \multirow[b]{2}{*}{$\begin{array}{c}\text { Mode } \\
1\end{array}$} & \multirow[b]{2}{*}{$\mathrm{R}$} & \multirow[b]{2}{*}{$\begin{array}{c}\mathrm{R} \\
\text { Square }\end{array}$} & \multirow[b]{2}{*}{$\begin{array}{c}\text { Adjusted } \\
\text { R } \\
\text { Square }\end{array}$} & \multirow{2}{*}{$\begin{array}{c}\text { Std. } \\
\text { Error of } \\
\text { the } \\
\text { Estimate }\end{array}$} & \multicolumn{5}{|c|}{ Change Statistics } & \multirow{2}{*}{$\begin{array}{c}\text { Durbin } \\
- \\
\text { Watso } \\
n\end{array}$} \\
\hline & & & & & $\begin{array}{c}\mathrm{R} \\
\text { Square } \\
\text { Change }\end{array}$ & $\begin{array}{c}\mathrm{F} \\
\text { Chang } \\
\mathrm{e} \\
\end{array}$ & df1 & df2 & $\begin{array}{c}\text { Sig. F } \\
\text { Chang } \\
\mathrm{e}\end{array}$ & \\
\hline 1 & $.823^{\mathrm{a}}$ & .678 & .356 & .8497230 & .678 & 2.104 & 2 & $2^{\mathrm{a}}$ & .322 & 2.195 \\
\hline
\end{tabular}

a. "Predictors (Constant), DAR, CR

b. Dependent Variable:PERUBAHAN LABA"

"Sumber : Output SPSS 20.0"

Berdasarkan tabel 4.3 didapatkan angka $\mathrm{R}$ sejumlah 0,823 antara selang 0,75 - 1". Hal ini menunjukan bahwa hubungan korelasi sangat kuat dengan arah hubungan positif antara Current Ratio (CR) dan Debt to Assets Ratio (DAR) terhadap perubahan laba.

\section{Determinasi}

"Koefisien determinasi menentukan seberapa besar kontribusi X terhadap penurunan Y". Dari tabulasi $4.4 \mathrm{R}$ Square 0,678 atau 67,8\%, artinya "dari perubahan laba dapat dijelaskan oleh Current ratio (CR) dan Debt to Assets Ratio (DAR)" dan sisanya 32,2\% (100\% - 67,8\%) dipengaruhi oleh variabel yang tidak digunakan dalam telaah ini seperti Perputaran total aset, Perputaran persediaan, Rasio cepat, Pengembalian modal, dan variabel lainnya.

D. Regresi Berganda

Tabulasi

Koefisien" Regresi Linier Berganda" Coefficients $^{\mathbf{a}}$

\begin{tabular}{|c|c|c|c|c|c|c|c|}
\hline \multirow{2}{*}{ Model } & \multicolumn{2}{|c|}{$\begin{array}{l}\text { Unstandardized } \\
\text { Coefficients }\end{array}$} & \multirow{2}{*}{$\begin{array}{c}\begin{array}{c}\text { Standardize } \\
\mathrm{d} \\
\text { Coefficients }\end{array} \\
\text { Beta }\end{array}$} & & \multirow{2}{*}{ Sig. } & \multicolumn{2}{|c|}{ Collinearity Statistics } \\
\hline & B & $\begin{array}{l}\text { Std. } \\
\text { Error }\end{array}$ & & & & Tolerance & VIF \\
\hline $\begin{array}{c}\text { (Constan } \\
\mathrm{t})\end{array}$ & .350 & 2.278 & & .153 & .892 & & \\
\hline $\mathrm{CR}$ & 2.966 & 1.939 & .615 & 1.529 & .266 & .997 & 1.003 \\
\hline DAR & -6.549 & 5.138 & -.513 & -1.275 & .330 & .997 & 1.003 \\
\hline
\end{tabular}

a. "Dependent Variable: PERUBAHAN LABA"

"Sumber: Output SPSS 20.0"

"Berdasarkan tabulasi 4.5" dapat diketahui persamaan regresinya yaitu : $\mathrm{Y}=0,350+2,966 \mathrm{X} 1-6,549 \mathrm{X} 2$

Persamaan regresi tersebut di atas dapat diinterprestasikan sebagai berikut :

1. Konstanta sebesar 0,350 artinya jika Current ratio (CR) dan Debt to Assets Ratio (DAR) nilainya 0, maka perubahan adalah 0,350 satuan.

2. Koefisien regresi variabel Current Ratio (CR) sebesar 2,966 artinya jika variabel independen lain nilainya nol dan jika Current Ratio (CR) mengalami kenaikan 1 unit, maka perubahan laba akan mengalami 
kenaikan sebesar 2,966 unit. Sebaliknya jika Current Ratio (CR) mengalami penurunan 1 unit maka perubahan laba akan mengalami penurunan sebesar 2,966 unit. Koefisien memili makna positif artinya terdapat hubungan positif antar variabel Current Ratio (CR) dan variabel perubahan laba.

3. "Koefisien regresi variabel Debt to Assets Ratio (DAR) sebesar - 6,549 artinya jika variabel independen lain nilainya nol dan jika Debt to Assets Ratio (DAR) mengalami kenaikan 1 satuan maka perubahan laba akan mengalami penurunan sebesar 6,549 satuan. Sebaliknya jika (DAR) mendapati penurunan 1 unit maka perubahan laba akan mendapati kenaikan sebesar 6,549 unit. Koefisien bernilai negatif artinya terdapat hubungan negatif antara variabel Debt to Assets Ratio (DAR) dengan variabel perubahan laba".

E. Hipotesis

1. Uji Parsial

Tabel

Uji T Parsial

Coefficients $^{\mathbf{a}}$

\begin{tabular}{|c|c|c|c|c|c|c|c|}
\hline \multirow{2}{*}{ Model } & \multicolumn{2}{|c|}{$\begin{array}{l}\text { Unstandardized } \\
\text { Coefficients }\end{array}$} & \multirow{2}{*}{$\begin{array}{c}\begin{array}{c}\text { Standardize } \\
\mathrm{d} \\
\text { Coefficients }\end{array} \\
\text { Beta }\end{array}$} & \multirow{2}{*}{$\mathrm{t}$} & \multirow{2}{*}{ Sig. } & \multicolumn{2}{|c|}{ Collinearity Statistics } \\
\hline & B & $\begin{array}{l}\text { Std. } \\
\text { Error }\end{array}$ & & & & Tolerance & VIF \\
\hline $\begin{array}{c}\text { (Constan } \\
\text { t) }\end{array}$ & .350 & 2.278 & & .153 & .892 & & \\
\hline $\mathrm{CR}$ & 2.966 & 1.939 & .615 & 1.529 & .266 & .997 & 1.003 \\
\hline DAR & -6.549 & 5.138 & -.513 & -1.275 & .330 & .997 & 1.003 \\
\hline
\end{tabular}

a. "Dependent Variable: PERUBAHAN LABA"

"Sumber : Output SPSS 20.0"

"Dari tabulasi 4.6 hasil $\mathrm{t}$ hitung $(1,529)<\mathrm{t}$ tabel $(2,919)$ atau menggunakan significant level 0,266 " lebih besar dari $0,05(0,266>0,05)$, maka Ho diterima dan Ha ditolak, sehingga dari hasil tersebut dapat disimpulkan bahwa secara parsial (sendiri-sendiri) tidak ada pengaruh yang signifikan antara (CR) terhadap perubahan laba".

Dari tabulasi 4.6 hasil $\mathrm{t}$ hitung $(-1,275)<\mathrm{t}$ tabel $(-2,919)$ atau menggunakan significant level 0.330 "lebih besar dari $0,05(0,330>0,05)$, maka Ho diterima dan Ha ditolak, sehingga dari hasil tersebut dapat disimpulkan bahwa secara parsial (sendiri-sendiri) tidak ada pengaruh yang signifikan antara Debt to Assets Ratio (DAR) terhadap perubahan laba".

\section{Uji Simultan}

Tabulasi

Uji F Simultan

ANOVA $^{\mathrm{a}}$

\begin{tabular}{|rl|r|r|r|c|c|}
\hline Model & $\begin{array}{r}\text { Sum of } \\
\text { Squares }\end{array}$ & Df & $\begin{array}{c}\text { Mean } \\
\text { Square }\end{array}$ & F & Sig. \\
\hline \multirow{2}{*}{1} & Regression & 3.038 & 2 & 1.519 & 2.104 & $.322^{\mathrm{b}}$ \\
\cline { 3 - 4 } & Residual & 1.444 & 2 & .722 & & \\
\hline
\end{tabular}




\section{F. Pembahasan}

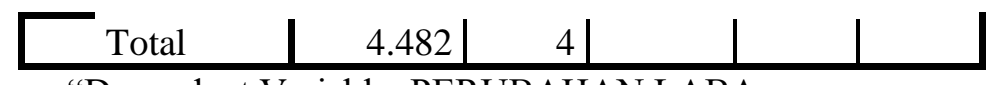

a. "Dependent Variable: PERUBAHAN LABA

b. Predictors: (Constant), DAR, CR"

"Sumber: Output SPSS 20.0"

"Dari tabulasi 4.7" tersebut, hasil f hitung $(2,104)<\mathrm{f}$ tabel $(19,00)$ atau menggunakan significant level yaitu 0,322 karena 0,322 lebih besar dari $0,05(0,322>0,05)$ maka Ho diterima dan Ha ditolak, artinya "tidak ada pengaruh secara signifikan antara" Current Ratio (CR) dan Debt to Assets Ratio (DAR) secara simultan (bersama-sama) terhadap perubahan laba.

"Berdasarkan hasil-hasil yang dibahas dan diuraikan diatas maka didapatkan hasil sebagai berikut" :

1. Dari hasil koefisien korelasi diperoleh angka $\mathrm{R}$ sebesar 0,823 terletak diantara interval $0,75-1$. Hal ini menunjukan bahwa hubungan korelasi sangat kuat dengan arah hubungan positif antara Current Ratio (CR) dan Debt to Assets Ratio (DAR) terhadap perubahan laba.

2. Dari hasil uji t dapat dilihat bahwa" secara parsial (sendiri-sendiri) tidak ada pengaruh yang signifikan antara Current Ratio (CR) terhadap perubahan laba karena memiliki nilai signifikan 0,266 > 0,05". Current ratio (CR) yang tinggi memberikan indikasi bahwa terdapat aktiva lancar yang terlalu banyak serta tidak produktif di dalam perusahaan. Hal ini menyebabkan adanya tingkat piutang yang relatif besar didalam aktiva lancar. Dengan tingkat piutang yang tinggi akan berdampak tidak menghasilkan penjualan yang mengakibatkan laba menurun. Dari hasil uji $\mathrm{t}$ dapat dilihat "bahwa secara parsial (sendiri-sendiri) tidak ada pengaruh yang signifikan antara Debt to Assets Ratio (DAR) terhadap perubahan laba karena memiliki nilai signifikan $0,330>0,05$ ". Debt to "Assets Ratio merupakan rasio hutang yang digunakan untuk mengukur perbandingan antara total utang dengan total aktiva". "Apabila total hutang naik maka akan mengakibatkan interest naik". Namun jika kenaikan total hutang digunakan secara produktif maka akan menghasilkan penjualan yang lebih besar, sehingga berakibat laba cenderung naik.

3. "Dari hasil uji $\mathrm{f}$ juga didapat hasil tidak ada pengaruh secara signifikan antara Current Ratio (CR) dan Debt to Assets Ratio (DAR)" secara simultan (bersama-sama) terhadap perubahan laba. Sehingga dapat dikatakan bahwa antara Current Ratio (CR) dan Debt to Assets Ratio (DAR) secara simultan (bersama-sama) tidak memiliki pengaruh terhadap perubahan laba.

Tabel

Korelasi atau hubungan

\begin{tabular}{|l|l|}
\hline \multicolumn{1}{|c|}{ Variabel } & \multicolumn{1}{|c|}{ Perubahan laba } \\
\hline $\begin{array}{l}\text { Current Ratio (CR) dan Debt } \\
\text { to Assets Ratio (DAR) }\end{array}$ & Korelasi sebesar 0.823, korelasi sangat kuat dan positif \\
\hline
\end{tabular}

Sumber : data yang sudah diolah

Tabel

Rangkuman

\begin{tabular}{c|c|c|c|c|}
\hline $\mathrm{Xi}$ & Nama Variabel & Berpengaruh & Tidak & Variabel \\
\hline
\end{tabular}




\begin{tabular}{|l|l|c|c|l|}
\hline & & & berpengaruh & \multicolumn{1}{|c|}{ dependen } \\
\hline \multicolumn{5}{|c|}{ Secara Parsial (sendiri-sendiri) } \\
\hline X1 & $\begin{array}{l}\text { Current Ratio (CR) } \\
\text { X2 }\end{array}$ & $\begin{array}{l}\text { Debt to Assets Ratio } \\
\text { (DAR) }\end{array}$ & $\checkmark$ & $\begin{array}{l}\text { Perubahan } \\
\text { Laba }\end{array}$ \\
\hline \multicolumn{5}{|c|}{ Secara Simultan (bersama-sama) } \\
\hline X1 & $\begin{array}{l}\text { Current Ratio (CR) } \\
\text { X2 }\end{array}$ & $\begin{array}{l}\text { Debt to Assets Ratio } \\
\text { (DAR) }\end{array}$ & $\checkmark$ & $\begin{array}{l}\text { Perubahanan } \\
\text { Laba }\end{array}$ \\
\hline
\end{tabular}

Sumber : data yang sudah diolah

\section{PENUTUP}

\section{A. Kesimpulan}

Penelitian ini bertujuan untuk menganalisis pengaruh rasio keuangan yaitu Current Ratio (CR) danDebt to Assets Ratio (DAR) terhadap perubahan laba pada PT Astra Agro Lestari Tbk periode 2012-2016. Berdasarkan hasil penelitian dan pembahasan sebelumnya maka dapat disimpulkan bahwa :

1. "Berdasarkan pengujian parsial dengan uji $\mathrm{t}$, diperoleh hasil t hitung $(1,529)<\mathrm{t}$ tabel $(2,919)$ atau menggunakan significant level 0,266 lebih besar dari 0,05 (0,266>0,05), maka Ho diterima dan Ha ditolak, sehingga dari hasil tersebut dapat disimpulkan bahwa secara parsial (sendiri-sendiri) tidak ada pengaruh yang signifikan antara Current Ratio (CR) terhadap perubahan laba pada PT Astra Agro Lestari Tbk periode 2012-2016".

2. "Berdasarkan pengujian parsial dengan uji $t$, diperoleh hasil $t$ hitung ($1,275)<\mathrm{t}$ tabel $(-2,919)$ atau menggunakan significant level 0.330 lebih besar dari $0,05(0,330>0,05)$, maka Ho diterima dan Ha ditolak, sehingga dari hasil tersebut dapat disimpulkan bahwa secara parsial (sendiri-sendiri) tidak ada pengaruh yang signifikan antara Debt To Total Assets Ratio (DAR) terhadap perubahan laba pada PT Astra Agro Lestari Tbk periode 2012-2016".

3. "Berdasarkan pengujian simultan dengan uji $\mathrm{f}$, diperoleh hasil $\mathrm{f}$ hitung $(2,104)<\mathrm{f}$ tabel $(19,00)$ atau menggunakan significant level yaitu 0,322 karena 0,322 lebih besar dari 0,05 $(0,322>0,05)$ maka Ho diterima dan Ha ditolak, sehingga tidak ada pengaruh secara signifikan antara Current Ratio (CR) dan Debt To Total Assets Ratio (DAR) secara simultan (bersama-sama) terhadap perubahan laba pada PT Astra Agro Lestari Tbk periode 2012-2016".

\section{B. Saran}

"Berdasarkan penelitian yang telah dilakukan, peneliti memberikan beberapa saran sebagai berikut " :

1. "Bagi peneliti selanjutnya yang akan melakukan penelitian dengan topik sama disarankan untuk menggunakan variabel yang lain diluar variabel yang telah dianalisis dalam penelitian ini dan hendaknya untuk menambah jenis perusahaan lain sebagai objek sehingga hasil penelitian ini menjadi lebih beragam dan lebih akurat". 
2. Bagi investor tentunya hasil penelitian ini bisa dijadikan acuan atau pedoman dalam menganalisis laporan keuangan dengan menggunakan variabel yang lain, yang dapat mempengaruhi naik dan turunnya perubahan laba perusahaan tersebut.

3. "Bagi perusahaan hasil penelitian ini dapat dijadikan alat evaluasi kinerja manajemen selama ini, apakah mereka telah bekerja secara efektif atau tidak. Jika berhasil mencapai target yang telah ditentukan mereka dikatakan telah berhasil mencapai target untuk beberapa periode begitupun sebaliknya. Manajemen perusahaan harus lebih efisien dan efektif dalam mengelola aset yang dimiliki, biaya-biaya yang dikeluarkan selama satu periode berjalan, sehingga perusahaan dapat menghasilkan laba yang tinggi setiap tahunnya. Hal tersebut dapat memberikan kepercayaan untuk meyakinkan investor menginvestasikan dananya ke perusahaan".

\section{DAFTAR PUSTAKA}

Agustini. 2013. Pengelolaan dan Unsur-unsur Manajemen. Jakarta: Citra Pustaka Appley dan Oey Liang Lee. 2010. Penghantar Manajemen. Jakarta : Salemba Empat

Bambang, Riyanto. 2010. Dasar-dasar Pembelajaran Perusahaan. Edisi ke 4.Yogyakarta : BPFE

Darsono. 2011. Manajemen Keuangan. Jakarta : Consultsant Accounting

Fahmi, Irham. 2013. Penghantar Manajemen Keuangan. Edisi ke 2. Bandung : ALFABETA

Ghozali, Imam. 2010. Teori, Konsep dan Aplikasi Dengan SPSS 17. Semarang : Badan Penerbit Universitas Diponegoro.

Halim, Abdul dan Bambang Supomo. 2010. Manajemen Bisnis. Bogor : Ghalia Indonesia

Hanafi. 2012. Analisis Laporan Keuangan. Edisi ke 3. Cetakan Pertama. Yogyakarta : UPP STIM YKPN

Harahap, Sofyan Syafri. 2013. Analisis Kritis Atas Laporan Keuangan. Jakarta: PT Raja Grafindo Persada.

Harahap. 2013. Analisis Kritis Atas Laporan Keuangan.Edisi ke 11.Jakarta : Rajawali Pers

\section{Sumber Internet :}

http://www.idx.co.id, diakses pada tanggal 1 Oktober 2017, pukul 08.50PM

http://www.astra-agro.co.id, diakses pada tanggal 3 Oktober 2017, pukul 09.50 PM. 